\title{
Notes on Three Marine Algal Species from Korea
}

\author{
Pil Joon $\mathrm{KANG} \cdot \mathrm{Ki}$ Wan $\mathrm{NAM}^{\dagger}$ \\ (Pukyong National University) \\ 한국산 해조 3종에 대한 주해 \\ 강필준 · 남기완 ${ }^{\dagger}$ \\ (부경대학교)
}

\begin{abstract}
한국산 해조 3종, Umbraulva olivascens (P.J.L. Dangeard) G. Furnari, Bryopsis minor Womersley, Sargassum polycystum C. Agardh에 대한 형태학적 및 분류학적 주해가 제시된다. Umbraulva olivascens 는 뚜렷한 올리브 체색, 파상형 연변, 엽체의 구멍 및 조하대 서식처에 의해 특징지어진다. Bryopsis minor는 작은 조체, 모든 방향에서 많은 분지, 기부에 잘록함이 없는 선형의 소지, 두드러진 가지 흔 적을 결여하는 축, 뚜렷한 중심 피레노이드를 갖는 엽록체, 주축과 비슷한 길이의 가지 및 뚜렷하지 않은 주축을 갖는 것이 특징적이다. Sargassum polycystum은 조체 모든 부분에서 나는 원통형 내지 난형의 돌기, 가시가 있는 뚜렷한 중륵을 갖는 전연 내지 다소 거치연의 잎과 드물게 나는 기낭을 갖는 것으로 특징지어진다. 이 3종은 여기서 한국 해조상에 처음 기록된다.
\end{abstract}

\section{Key words : First record, Umbraulva olivascens, Bryopsis minor, Sargassum polycystum, Korea}

Since Kang (1966), occurrence of many marine algal species has been reported from Korea (Lee and Kang, 1986; 2002; Kang and Nam, 2011). Up to now, about 900 species have been recorded in the Korean marine algal flora (Boo and Ko, 2012). In the course of a survey of indigenous biological resources, three marine algal species, Umbraulva olivascens (P.J.L. Dangeard) G. Furnari (Ulvaceae), Bryopsis minor Womersley (Bryopsidaceae), Sargassum polycystum C. Agardh (Sargassaceae), were collected from Korea, and morphological and taxonomic notes on these species are given here. This is the first record of those three species from Korea.

Umbraulva olivascens (P.J.L. Dangeard) G. Furnari in Catra, Alongi, Serio, Cormaci \& G. Furnari 2006 (Fig. 1)

Korean name: Gu-meong-cho-rok-gal-pa-rae nom. nov. (구멍초록갈파래: 신칭).

Specimens examined: KOSPAL 0000126293, PKNU 0000126294, PKNU 0000126295 (Gujwa: 25.xi.2011).

Habitat: Epilithic in subtidal.

Morphology: Thalli up to $5-10 \mathrm{~cm}$ high, epilithic,

† Corresponding author : 051-629-5922, kwnam@pknu.ac.kr

* This work was supported by a grant from the National Institute of Biological Resources (NIBR), funded by the Ministry of Environment (MOE) of the Republic of Korea (2011) and by a grant from Marine Biotechnology Program funded by Ministry of Oceans and Fisheries of Korean Government. 


\section{Pil Joon Kang $\cdot$ Ki Wan Nam}

solitary, erect from discoid holdfast, olive-green in color; blades rigid, elliptical to linear, with undulate margin having protuberances, sometimes with perforation, 80-120 $\mu \mathrm{m}$ thick in upper part, $300-400 \mu \mathrm{m}$ in basal part; cells elliptical to polygonal, $10-15 \times 12-20 \mu \mathrm{m}$ in surface view; rhizoidal cells dark olive green, numerous near basal portion; chloroplast parietal, with 1-3 pyrenoids.

Remarks: Umbraulva was recently established based on distinct olive-green colored blade, containing siphonaxanthin pigment, subtidal habitat and molecular evidence (Bae and Lee, 2001). Three species are currently recognized in this genus. Of these, $U$. japonica (type) and $U$. amamiensis have been reported from Korea (Bae and Lee, 2001). Umbraulva olivascens described from Roscoff differs from the two species in presence or absence of perforations on blade, undulate margin and fluorescence. Our plants have rigid thalli in distinct olive-green color in subtidal as Umbraulva. They are identified as $U$. olivascens based on the undulate margin and perforations on blade, although those specimens show more or less small size $(5-10 \mathrm{~cm})$ and elliptical to linear shape rather than big size $(10-20 \mathrm{~cm})$ and orbicular to irregularly round shape found in $U$. olivascens. This is the first record of $U$. olivascens from Korea.

\section{Bryopsis minor Womersley 1955 (Fig. 2)}

Korean name: Jag-eun-git-teol-mal nom. nov. (작 은깃털말: 신칭).

Specimens examined: KOSPAL 0000126296, PKNU 0000126297 (Guryongpo: 9.ix.2011).

Habitat: Epiphytic on other algae.

Morphology: Thalli up to $2-3 \mathrm{~cm}$ high, tuft, epiphytic, bright green in color, attached by rhizoid; main axis indistinct, issuing numerous branches on all sides, sometimes naked near basal portion, without prominent branch scars, 200-500 $\mu \mathrm{m}$ in diam.; branches cylindrical, linear, with numerous branchlets on all sides, 100-200 $\mu \mathrm{m}$ in diam.; branchlets constricted at base, without septum, 20-50 $\mu \mathrm{m}$ in diam.; chloroplasts round, 8-12 $\mu \mathrm{m}$ long, with a central pyrenoid.

Remarks: Bryopsis minor was described from southern Australia (Womersley, 1955). According to the original description, this species is characterized by small thalli (up to $2 \mathrm{~cm}$ high), much branched thalli on all sides, slender and linear branchlets with basal constriction, axes without prominent branch scars, chloroplasts with a prominent central pyrenoid. Similar branches to main axes in length and indistinct axes appear to be also distinct for $B$. minor (Huisman, 2000). Our specimens fit well with the original and Huisman's description. This is the first record of $B$. minor from Korea.

\section{Sargassum polycystum C. Agardh 1824 (Fig. 3)}

Korean name: Dol-gi-mo-ja-ban nom. nov. (돌 기모자반: 신칭).

Specimens examined: KOSPAL 0000126298, PKNU 0000126299, PKNU 0000126300 (Gujwa: 25.xi.2011).

Habitat: Growing on rock near lower intertidal to subtidal.

Morphology: Thalli up 15-30 cm high, attached by discoid holdfast, up to $0.5-1.0 \mathrm{~cm}$ in diam.; stem erect, terete, 1-2 cm long, 2-4 $\mathrm{mm}$ broad; axes terete to triquetrous, with numerous cylindrical to oval elevated cryptostomata 200-300 $\mu \mathrm{m}$ long, 2-5 $\mathrm{mm}$ in diam.; lateral branches well developed; leaves arranged spirally, long, elliptical to lanceolate, entire to slightly serrulate in margin, with usually distinct midrib bearing spines near basal portion, 5-50 $\mathrm{mm}$ long, 2-20 mm broad; cryptostomata scattered on all parts of thallus; vesicle absent to rare, ovoid. 

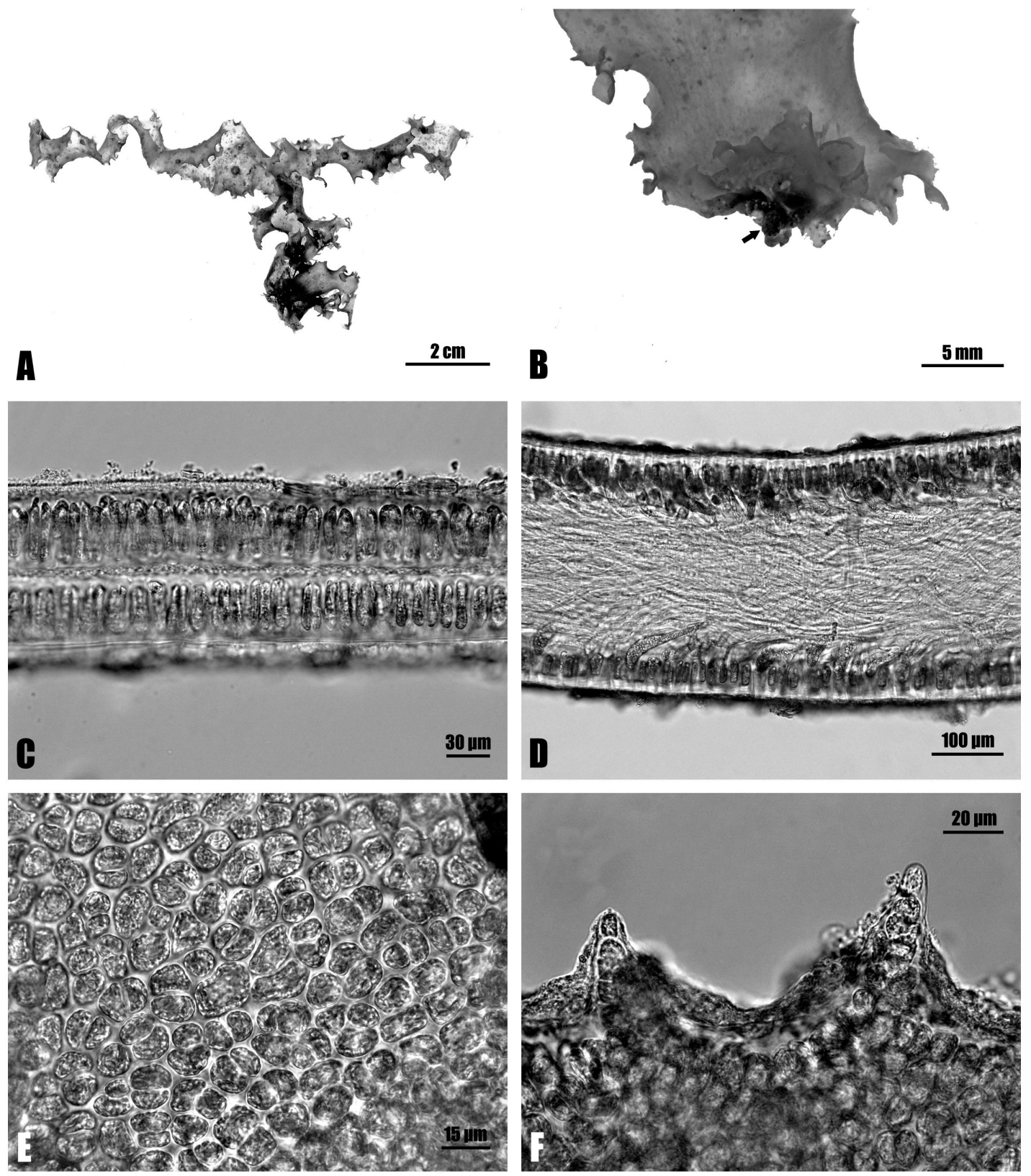

[Fig. 1] Umbraulva olivascens (P.J.L. Dangeard) G. Furnari. A, Habit of vegetative plant; B, Basal discoid holdfast (arrow); C, Non-rhizoidal cells in transverse section of upper thallus; D, Rhizoidal cells in transverse section of basal thallus; E, Epidermal cells in surface view; F, Protuberances along undulate margin. 
Pil Joon Kang $\cdot$ Ki Wan Nam
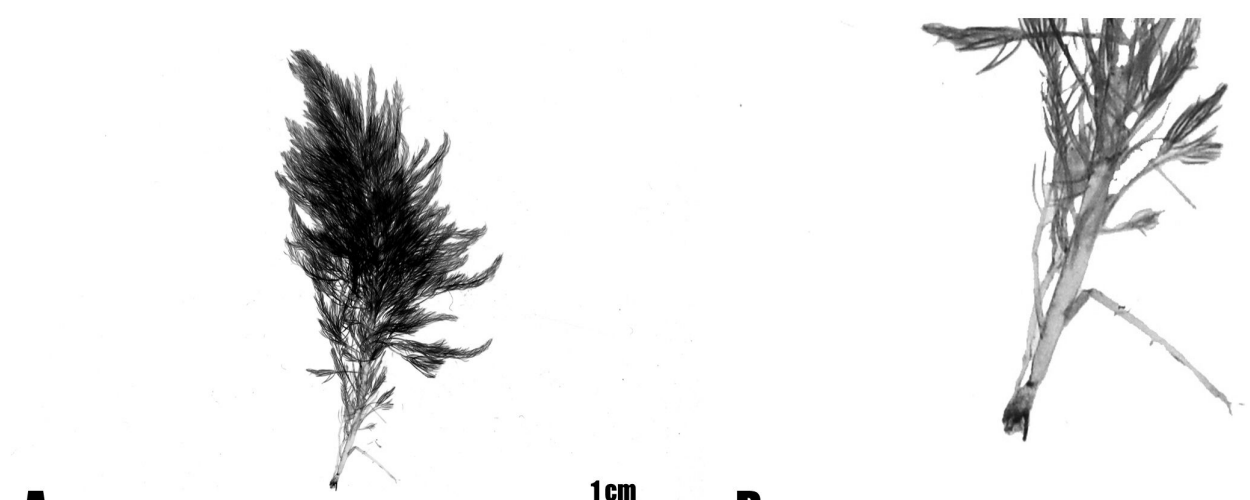

A
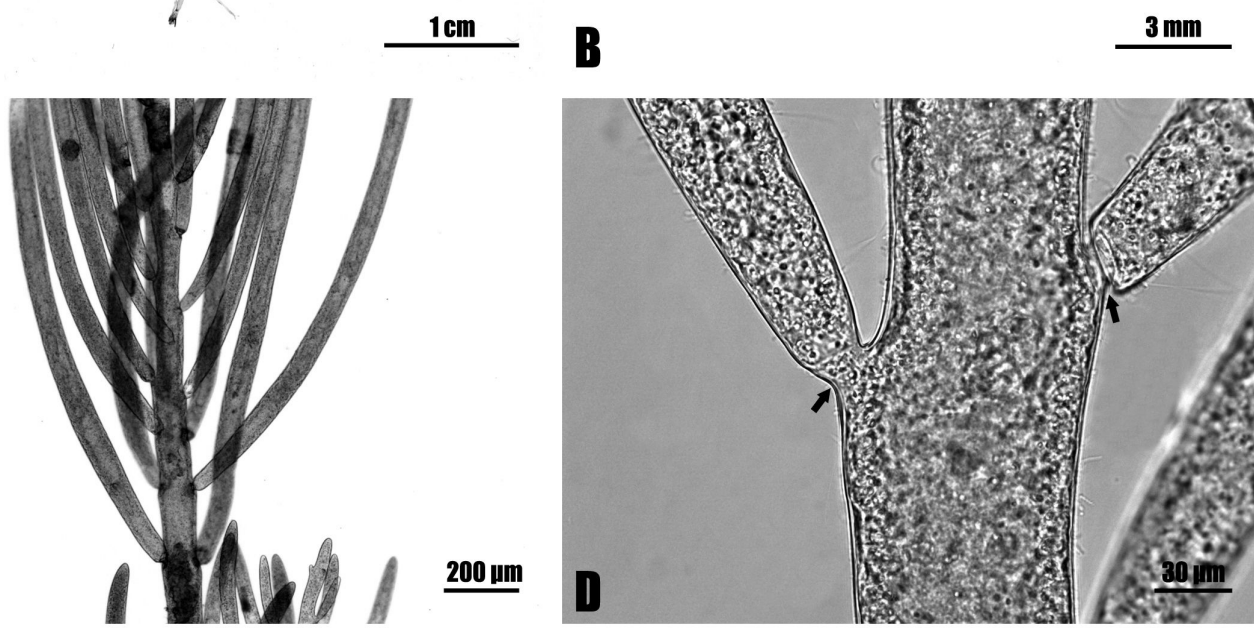

$\boldsymbol{B}$

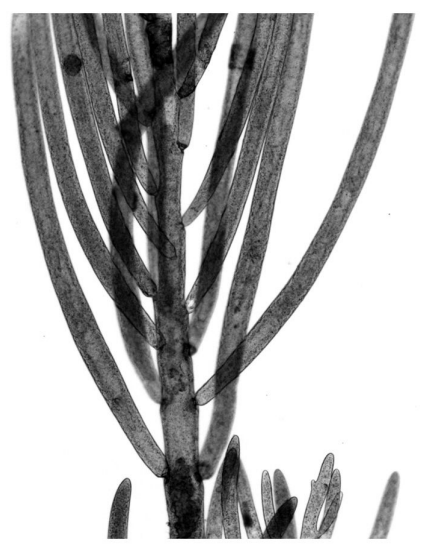

$\underline{200 u m}$

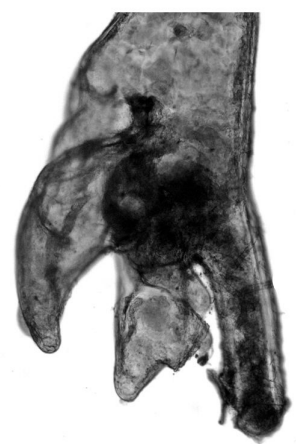

$\mathbf{E}$

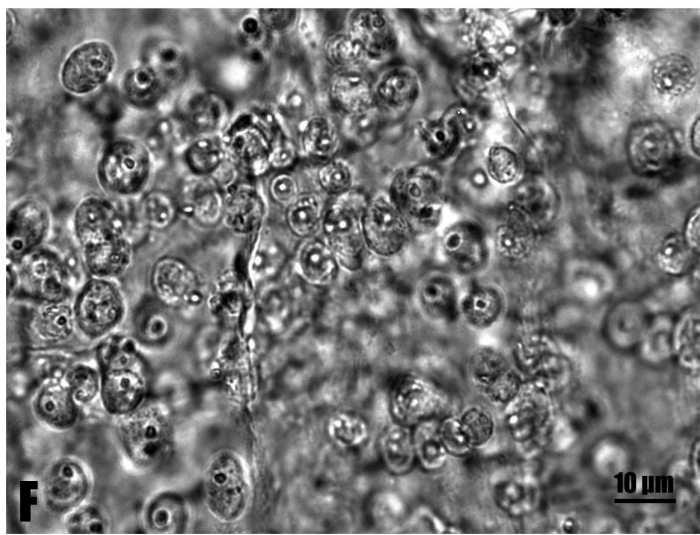

[Fig. 2] Bryopsis minor Womersley. A, Habit of vegetative plant without distinct main axis; B, Naked basal portion of thallus; C, Details of lateral branches; D, Branches with basal constriction (arrows) lacking septum; E, Rhizoidal holdfast; F, Round chloroplasts with central pyrenoid. 

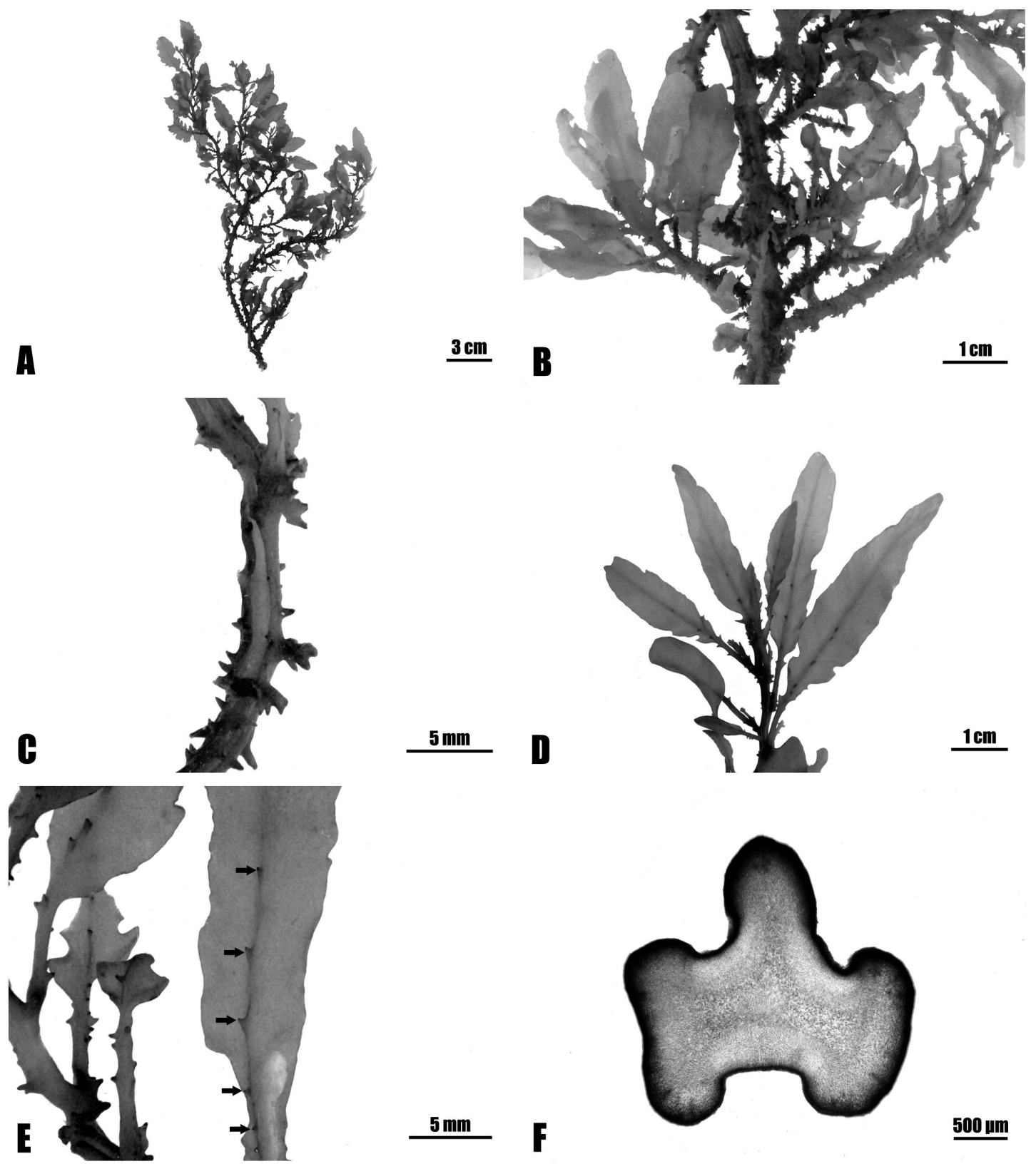

[Fig. 3] Sargassum polycystum C. Agardh. A, Habit of vegetative plant; B, Details of vegetative branches; C, Axis with many projections; D, Elliptical to lanceolate leaves with distinct midrib; $\mathrm{E}$, Details of leaves with spines (arrows) along midrib; F, Triquetrous main axis in transverse section. 
Remarks: Since Agardh (1824), Sargassum polycystum has been reported from many East Asian countries including China and Japan. However, occurrence of this species has not been reported from Korea. Sargassum polycystum appears to be distinct from other Korean Sargassum species in having cylindrical to oval elevated projections (= cryptostomata) on all parts of thallus, entire to slightly serrulate margin with distinct midrib bearing spines and in lacking or having rarely vesicle (the present study). These features are found in our specimens. So our Korean specimens are identified as this species based on the present and previous observations (Agardh, 1824; Chiang et al., 1992; Yoshida, 1998; Kraft, 2009). This is the first record of $S$. polycystum from Korea.

\section{References}

Agardh, C.A.(1824). Systema Algarum, Berling, Lund. Bae, E.H. and Lee, I.K.(2001). Umbraulva, a new genus based on Ulva japonica (Holmes) Papenfuss (Ulvaceae, Chlorophyta). Algae 16(3), 217 231.

Boo, S.M. and Ko. Y.D.(2012). Marine plants from Korea. Seoul: Junghaeng-Sa.

Catra, M. - Alongi, G. · Serio, D. · Cormaci, M. and Furnari, G.(2006). The benthic algal flora on rocky substrata of the Egadi islands, a marine protected archipelago off the western coast of Sicily (Italy, Mediterranean Sea). Nova Hedwigia 82, 489 538.

Chiang, Y.-M. · Yoshida, T. • Ajisaka, T. • Trono, G.Jr. - Tseng, C.K. and Baoren, L.(1992).
Distribution and variation in Sargassum polycystum C.A. Agardh (Fucales, Phaeophyta). In: Taxonomy of Economic Seaweeds with reference to some Pacific and Western Atlantic species. (Abbott, I.A. Ed.) 3, 35 42. La Jolla, California: California Sea Grant College.

Huisman, J.M.(2000). Marine plants of Australia. Melbourne: UWA press.

Kang, J.W.(1966). On the geographical distribution of marine algae in Korea. Bulletin of Pusan Fisheries College 7, 1 125.

Kang, P.J. and Nam, K.W.(2011). First record of Neorhodomela larix (Turner) Masuda (Rhodomela ceae, Rhodophyta) in Korea, Journal of Fisheries and Marine Sciences Education 23(1), 126 129.

Kraft, G.T.(2009). Algae of Australia: Marine benthic algae of Lord Howe Island and the southern Great Barrier Reef, 2. Brown algae. Canberra: ABRS; Melbourne: CSIRO Publishing.

Lee, I.K. and Kang, J.W.(1986). A check list of marine algae in Korea. The Korean Journal of Phycology 1(1), 311 325.

Lee, Y.P. and Kang, S.Y.(2002). A catalogue of the seaweeds in Korea. Jeju: Jeju National University Press.

Womersley, H.B.S.(1955). New marine chlorophyta from southern Australia. Pacific Science 9, 387 395.

Yoshida, T.(1998). Marine algae of Japan. Tokyo: Uchida Rokakuho Publishing.

- 논문접수일 : 2013년 06월 29일

- 심사완료일 : 1차 - 2013년 07월 30일

- 게재확정일 : 2013년 08월 02일 